\title{
Environmental Dynamics and Its Impact on Agricultur- al Sustainability in Some Vulnerable Areas of Ethiopia Since 1900's: An overview
}

\author{
Endalkachew Lelisa Duressa \\ Department of History and Heritage Management, College of Social Science and Humanities, Bule Hora \\ University, Ethiopia. E-mail: endalkld@gmail.com
}

\begin{abstract}
This review primarily focuses on 'Environmental Dynamics and its impact on Agricultural Sustainability in some vulnerable areas of Ethiopia since 1900's'. The Significance of this study is to review and provide a summary of existing works of several authors and their perspectives on the environmental changing aspect over periods and the impact of the environment on human livelihood. To understand the problem of environmental change over periods, it is better to have historical knowledge through studying human impact on the environment and environmental impact on human livelihood. The data in this review consisted of both primary and secondary sources. Primary sources are obtained from concerned informants who have direct relationships with agriculture and the environments. Secondary sources in this study also consisted of both published and unpublished data from several disciplines related to environmental history. Collected data would be described, expressed and articulated qualitatively. All the data would be reviewed carefully and interpreted accordingly. The findings of the study revealed that different man-made and natural factors could be attributed to changes in the physical environment. In the past, it seems that only small efforts have been made up to date with the Environmental concern in Ethiopia. As a result, environmental degradation is responsible for the socioeconomic impacts of human livelihood. Today the government has been giving significant value to environmental conservation and management. The government attempts to address the environmental challenges that the country has been facing and suggests possible solutions to overcome, and hence move towards more sustainable development. Therefore, this review could be considered as a stepping stone for environmentalists and policy planners in making any particular policies and strategies in environmental impact management in Ethiopia.
\end{abstract}

Key words: Environment; Environmental Dynamics; Agriculture; Conservation; Agriculture Sustainability; Ethiopia

\section{INTRODUCTION}

As a discipline Environmental history is an issue that deals with the impact of past human societies on the natural environment and environmental impact on human society. More specifically, the principal goal of environmental history is to deepen our understanding of how nature influences humans, how humans intervene in nature and how nature and humans interact. Therefore, this is called the bilateral approach to environmental history. The contribution of other related disciplines such as geography, geology, biology, and many others is very important for the full concept of environmental history. There are also different scholarly perspectives on the dynamics of the physical environment in Ethiopia. So far there have been a few studies on humanenvironment interactions and environmental changes in Ethiopia. However, with a few exceptions, historians have not engaged in historicizing environmental changes in Ethiopia. Therefore, to understand the present problem of environmental dynamics, it is pivotal to have historical knowledge through studying the changes and continuities; cause and consequences of environmental crisis [1]. 
To understand the present problems of environmental change and its associated challenges, it is better to have historical knowledge through studying the changes and continuities in the physical and natural environment. These aspects are the political economy of land tenure, Agricultural production, socioeconomic changes, drought, famine and epidemic disease concerning to the natural environment at different levels. In line with this, scholars argue that a human being has been the major agent of environmental transformation. So, it is important to study the changes observed in the physical environment as an integral part of human livelihood. Moreover, the contemporary changes in the physical environment could be understood only when man-nature interaction and its mutual effects are investigated historically [2].

Recent studies show that the Ethiopian environment has been deteriorating from time to time and it challenges the country to ensure sustainable development. Different man-made and natural factors could be attributed to these changes in the physical environment. The major driving forces that changed the local environment are uncontrolled human intervention. There are high rates of deforestation, over-harvesting and energy consumption, urbanization, pollution, hazardous and untreated wastes, and civil war. To some extent, natural factors like earthquakes, active volcanoes, desertification, erosion, and water shortages have their own contributions to the changes observed in the natural environment [3].

As a result of global climatic changes with the local depletion and pollution of resources risked all forms of life in the country. For a century, there has been a decline in farming lands, destruction of natural habitat, and a decline in biological diversity, the spread of diseases, famine, and desertification in the country. More specifically, the southern Ethiopian region faced severs environmental degradation, climate change, and ecological crisis in the $19^{\text {th }}$ and $20^{\text {th }}$ centuries. The consequences of these environmental changes caused the decline of Agricultural productivity, recurrent drought, poverty, famine, unpredictable climatic change and epidemic diseases. At the same time, the state-local society conflict significantly affected the natural environment. Scholars agree that the wrong implementation of state and its policies with land, agriculture and other resources aggravated environmental degradation [4].

\section{Historical Evolution of Environimental Concern in ETHiopia}

In the $16^{\text {th }}$ century, the Oromo expansion and wars of Ahmad Gragn marked a new historical landscape in Ethiopia. These episodes changed deeply the demographic picture of the country and all this warfare and large geographical displacements in the country would probably have caused huge environmental degradation. In Ethiopia first environmental concern emerged from the latter years of Menelik's (1889-1913) regime with the growing fuel wood crisis in the country. These circumstances paved the way for the need for state protection of the forest and other resources. To solve this continuous loss of environmental resources impacts the Ministry of Agriculture was established in 1908. Consequently, the Ministry promoted good farming practices, increased agricultural and livestock production, environmental protection, disaster monitoring and prevention [5]. Nevertheless, as other scholars suggest, before the period of Italian occupation (1936-41), formal environmental decrees were rare in Ethiopia. The natural resource laws during the Italian occupation focused on the economic potential of natural resources rather than their environmental and ecological value [6].

Imperial environmental paradigm in Ethiopia until the latter parts of $1960 \mathrm{~s}$, were frontier economics. It marked economic bias as a result of the limited environmental awareness of policy makers. It was believed that managing natural resource like forest, water, soil, land and wildlife was to increase government revenue than evaluating its impact on human livelihood. Consequently, environmental management was more or less irrelevant because it was 'outside' economics. After the mid 1960s the frontier economics attitude decreased as pollution and biodiversity-loss problems became evident in the country. In fact, it was only at the end of 1970's that the major international donors began to be concerned and developed the tools like environmental impact assessment (EIA) in the Ethiopia to respond to environmental damage. But, still scholars argue as Ethiopia falls into frontier economics categories and postponed the environmental concern [7]. 
Similarly, Chala argue that, before 1945 the environmental issue in Ethiopia was considered as "Dark Age". Here the term 'Dark Age' implies the period when environmental issues are declined, the period when environmental degradations accelerated and the government policies excluded the environmental matters in Ethiopia. In Ethiopia, during the second half of the $20^{\text {th }}$ century, the country has experienced severe deforestations and degradation. The major pushing factors are agricultural expansion, population increase, unsustainable harvest of timber, fuel wood extraction, etc. Generally, recent studies confirmed as the Ethiopian environmental concerns in the $20^{\text {th }}$ century were poor. This was due to the ignorance of the indigenous knowledge of the local community, top-down approach of the government policies and legislation without the consent of the society [8].

It is believed that the result of misguided and unregulated modification of the Ethiopian environment, mishandling of natural ecological system, increased human and animal population leads to serious environmental degradation. As Bekele advocates, after the liberation of the Ethiopian imperial government (1941-1975), government policy focused on the development of the agricultural sector for domestic consumption and export. Therefore, as discussed above before 1945 Ethiopian have not a strong policy toward the environment. However, during the 1960s greater emphasis given to environmentalism and the interest of policymakers has been increased and some scholars consider this era as an 'environmental movement' in the country [9].

During the Derg regime (1974-1991) the paradigm seems to shift from the frontier economy to a somewhat mixed approach of the frontier economy and environmental conservation. Environmental policies produced during the Derg era were based on the socialist ideologies. Therefore, the Environmental legislation emanated from this socialist principle in which the role of the State as the owner of natural resources [10]. The nationalization of all lands, including forests in 1975 land reform brought some significant contribution to the forestry sectors. The government as well as donor agencies started to provide financial and technical assistance to the forestry sector. However, Melaku underscores that all rural land was nationalized without compensation and made the collective property of the people. Private ownership of rural land was prohibited, and the size of land for a household was limited [11].

The environmental policies of the Derg regime were characterized by top-down management policies, incorporated extensive conservation and tree-planting initiatives without careful planning, and lack of the merit of indigenous environmental conservation practices. Furthermore, the worst enemy of the state environmentalism under the Derg was the state itself, many of whose rural policies worked against environmental objectives. For instance, collectivization, resettlement and villagization program were aiming to reduce rural poverty and famine through maximizing agricultural productivity, promoting the rational land use, conserving resources and providing access to social services. But, as scholars suggest, villagization program could harm local resources, accelerate the spread of communicable diseases, and increase problems with plant pests and diseases. Later the resettled community starts to be the main actors of Environmental degradations. Therefore, the collection of famine and drought, Derg villagization, lack of land tenure security and some others aggravates the environmental degradation in the country [12].

However, when the Derg government lost power in 1991, most of the conservation and development activities in the environmental sector were destroyed. The transition from the Derg regime to the current EPRDF was accompanied by a radical ideological shift in the development of formal environmental institutions [13]. The main paradigm employed by EPRDF as an ideology to support the environment is frontier economies, resource managements and Eco-development. But the impacts of a sustainable environment for development have been questionable. On the other hand, a resource management paradigm is also ideologically accepted in the EPRDF as environmental paradigms [14].

\section{ENVironmental DEgradation AND Agricultural CRISIS IN ETHIOPIA}

The environmental crises in Ethiopia are similar to those of developing countries. In Ethiopia, the majority of 
the population lives in rural areas where agriculture is the main subsistence. Additionally, population pressure, agricultural expansion and increased livestock grazing pressure have contributed to increased deforestation and soil erosion in the central highlands [15]. The main environmental problems in Ethiopia are climate change, soil erosion, land degradation, desertification, indoor air pollution, water pollution and deforestation. Other important environmental challenges include loss of biodiversity and ecosystem services, declines in soil fertility and water quality, urban outdoor air pollution, and toxic household wastes. These issues can cause significant consequences for the population dependent upon the environment as their primary source of income. Additionally, the sociopolitical and economic challenges within Ethiopia can contribute to environmental degradation. Poor infrastructure, recurrent droughts, famines, and political unrest are additional challenges for the management of environmental resources in Ethiopia. [16].

In Ethiopia, agriculture contributes about 47\% GDP and 85\% of the Ethiopian population depend on agriculture directly or indirectly for their livelihoods. Ethiopia has great agricultural potential because of its vast areas of fertile land, diverse climate, and adequate rainfall. The main agricultural products are teff, sorghum, barley, wheat, corn, coffee and chat. Despite this potential, however, Ethiopian agriculture has remained underdeveloped. Because of drought, low productivity, weak infrastructure, low level of technology, high levels of taxation, overpopulation, and poor agricultural sector. Periodic crop failures and losses of livestock often occur when seasonal rains fail or when unusually heavy storms cause widespread flooding. More than $95 \%$ of the cultivated lands are under small-holder farmer's agriculture. The total impacts of land use of small-holder farmer have led to the overuse and degradation of these resources. [17].

In Ethiopia, a predominantly rural society, the life of peasants is rooted in the land, from which they eke out a meager existence. Through the ages, they have faced frequent natural disasters, armed conflict, and political repression, and in the process, they have suffered hunger, societal disruption, and death. Many other economic activities depend on agriculture, including the marketing, processing, and export of agricultural products. Consequently, for several years the country faced famine and drought that resulted in the death of millions of people from 1972 to 1974 and 1984 to 1986 [18].

McCann in his works discussed the agricultural history of the country and its crisis, he demonstrates the major approaches to the study of modern agriculture and the environmental history of the country. The author argues the impact of population pressure and its consequence, environmental degradation, climate change, and the prevalence of famine and epidemic diseases in the $19^{\text {th }}$ and $20^{\text {th }}$ centuries. However, he did not consider other socioeconomic and political factors to the changes in the physical environment and its impact on peasant life. [19].

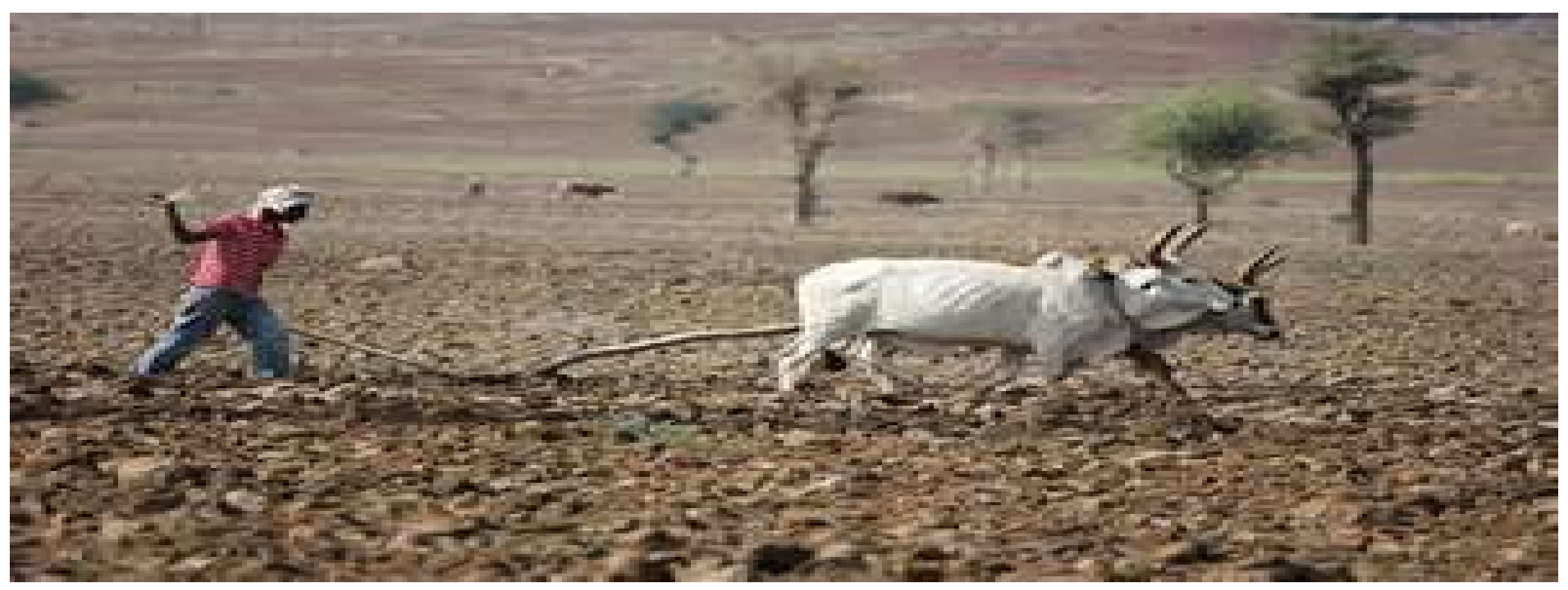

Figure 1: Traditional Farming System in Ethiopia 
Similarly, Crummye elucidates the political economy of land and the conflicts over the land in the country. He provides important insights into the nature of Ethiopian feudalism, class oppression and exploitation and conflicts of interests over the land. His works are important to understand the implications of land on socioeconomic and political forces of the natural environment. During the imperial period, the development of the agricultural sector was retarded by a number of factors, including tenancy and land reform problems, the neglect of the agricultural sector, low productivity, and lack of technological development [20].

The then government policy attempt to attract investors to import fertilizers, pesticides, tractors, combines, and encouraged the rapid expansion of large-scale commercial farming. As a result, agriculture continued to grow, even though below the population growth rate. According to the World Bank, agricultural production increased at an average annual rate of 2.1 percent between 1965 and 1973, while the population increased at an average annual rate of 2.6 percent during the same period [21].

A drought that began in 1969 continued as dry weather brought disaster to the Sahel and swept eastward through the Horn of Africa. By 1973 the attendant famine had threatened the lives of hundreds of thousands of Ethiopian. By the end of 1973, famine had claimed the lives of about 300,000 peasants of Tigray and Wollo, and thousands more had sought relief in Ethiopian towns and villages. Mesfin argues that famine in Ethiopia during imperial and the Derg periods was beyond environmental factors and it was aggravated by socioeconomic and political forces. He also discusses the process of environmental degradation, soil erosion and climate change in Central and Northern Ethiopia. As he agreed poverty and famine reduces people's capacity to use resources sustainably. Therefore, the current environmental problems and natural resource scarcity also caused interethnic conflict and increased competition over resources [22].

After assuming power in 1974, the military regime embarked on a program to improve the condition of peasants, but famine and hunger continued despite this effort by the government. The 1977-78 Ogaden War and the 1978 drought in eastern Ethiopia forced large numbers of people across the southeastern frontier into Somalia. Meanwhile, in the Ogaden, international relief agencies estimated the number of refugees entering Somali refugee camps at more than 1,000 a day. Drought, famine, government repression, and conflict with insurgents were the principal causes of these large scale refugee migrations. Most were women and children, and many suffered from dehydration, malnutrition, and diseases such as dysentery, malaria, and tuberculosis. The 1980s Ethiopia famine and hunger crisis were one of the worst humanitarian events of the 20th century. According to the United Nations report Ethiopia's food shortages and hunger crisis from 1983 to 1985 led to an estimated 1 million famine deaths. Millions more were displaced and left destitute, without resources to rebuild their lives. In 1987 another drought threatened 5 million people in Eritrea and Tigray. This time, however, the international community was better prepared to get food to the affected areas in time to prevent starvation and massive population movements [23].

Table 1. Environmental risk areas in Ethiopia from 1965 -2003

\begin{tabular}{|c|c|c|}
\hline Year & Nature of Disaster & Areas affected \\
\hline 1965 & Drought/ Famine & All provinces except Kaffa, Wolega and Illubabur \\
\hline 1968 & Flood & Southeast Ethiopia \\
\hline $1973 / 4$ & Drought/Famine & North Ethiopia \\
\hline 1983 & Drought/ Famine & Northern provinces of Eritrea, Gondor, Tigray and Wollo \\
\hline $1984 / 5$ & Drought/Famine/ Conflict & $\begin{array}{c}\text { Tigray, Wollo and Eritrea plus northern Shoa, Haraghe, Sidamo and Eastern } \\
\text { Gondor 10,803,080 people at risk }\end{array}$ \\
\hline 1986 & Pests disease & Wollo, Gondor, Tigray and Eritrea \\
\hline 1987 & Drought and Pests & All provinces were affected, except Gojam and Arsi. \\
\hline 1988 & Pests, drought, Conflict & Tigray, Eritrea, Hararghe, Wollo, Eastern Gondar. \\
\hline 1989 & Epidemic, and Conflict & Nationwide \\
\hline
\end{tabular}




\begin{tabular}{|c|c|c|}
\hline 1990 & Drought and Conflict & Northern Ethiopia, principally Tigray, Eritrea, Wollo \\
\hline 1991 & Drought and Conflict & Nationwide \\
\hline 1992 & Drought,Conflict, and Epidemic & All regions, except North Omo, East and West Gojam and Metekel. \\
\hline 1993 & Drought, Famine and Pandemic & $\begin{array}{c}\text { Tigray, Haraghe, Afar, Gondor, Wollo, Wellaga, Dire Dawa, Illubabor, Borena, } \\
\text { Ogaden. }\end{array}$ \\
\hline 1994 & Famine, and Drought & All regions. \\
\hline 1995 & Drought & $\begin{array}{l}\text { Lowlands of Tigray, highlands of North and South Wollo, North West Shoa } \\
\text { and East Hararghe }\end{array}$ \\
\hline $1996-8$ & Drought and Conflict & All regions \\
\hline 2002 & Drought & All regions. \\
\hline 2003 & Drought & $\begin{array}{c}\text { Lowlands and midlands of Afar, SNNPR, Tigray, Oromiya, and Amhara } \\
\text { regions. }\end{array}$ \\
\hline
\end{tabular}

Source: Sue Lautze, Yacob Aklilu, Angela Raven-Roberts, Helen Young, Girma Kebede, and Jennifer Leaning (2003)

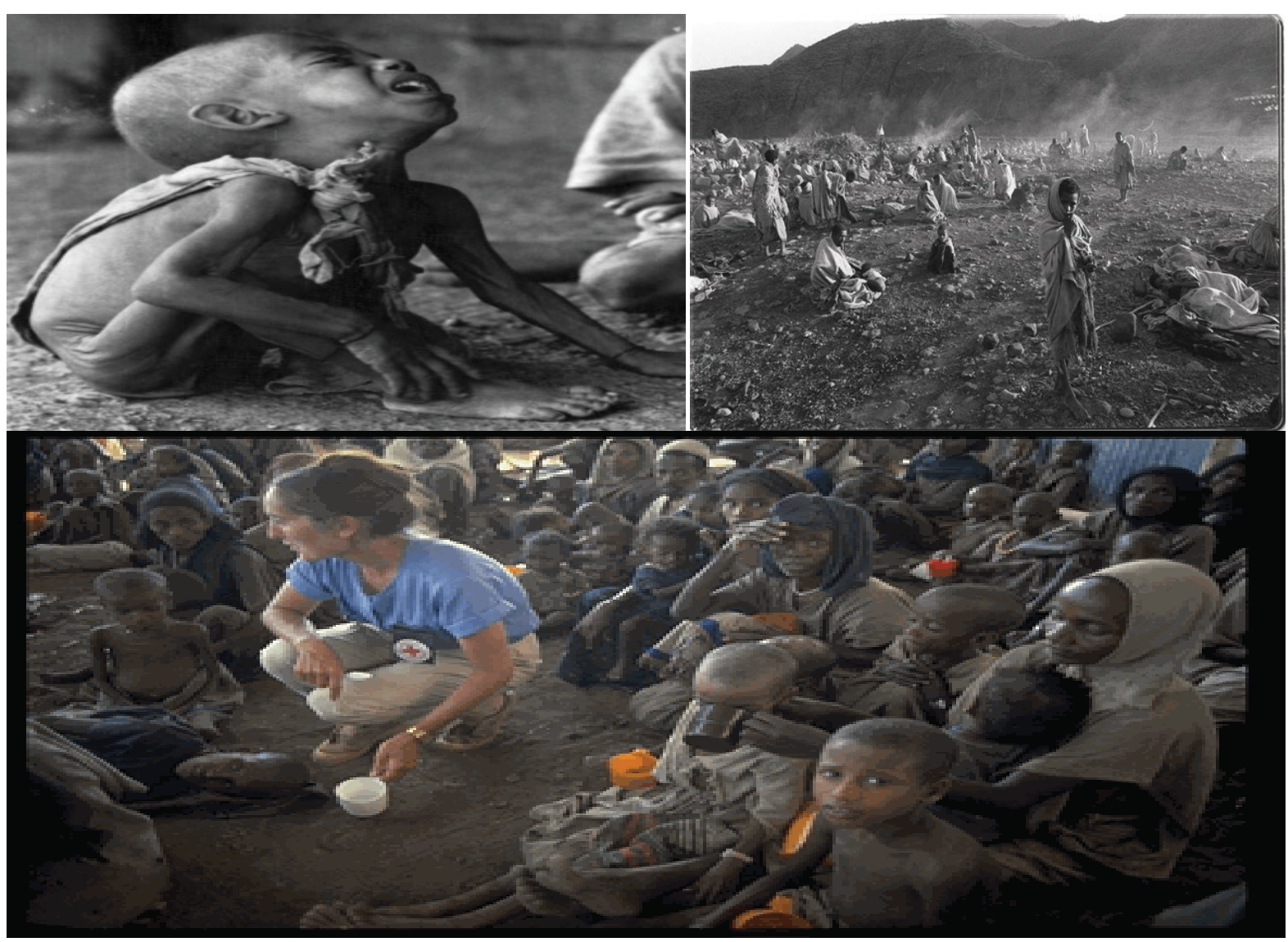

Figure 2: The memory of famine in Northern Ethiopia (Tigray and Wollo) in 1973/74

The government embarked on forced resettlement and villagization in the mid-1980s to combat drought, avert famine, and increase agricultural productivity. Resettlement, the regime's long term solution to the drought problem, involved the permanent relocation of about 1.5 million people from the drought prone areas of the north to the south and southwest, where population was relatively sparse and so called arable land was plentiful. 
These poor performance of agriculture during the Derg regime was related to several factors, including drought and famine; Prices controlling government policy and the free movement of agricultural products; the unstable political climate; the dislocation of the rural community and recruitment of young farmers to meet military obligations; land tenure difficulties and the problem of land fragmentation; the lack of farm inputs and the overall low level of technology. Most agricultural producers are subsistence farmers with small holdings, often broken into several plots [23].

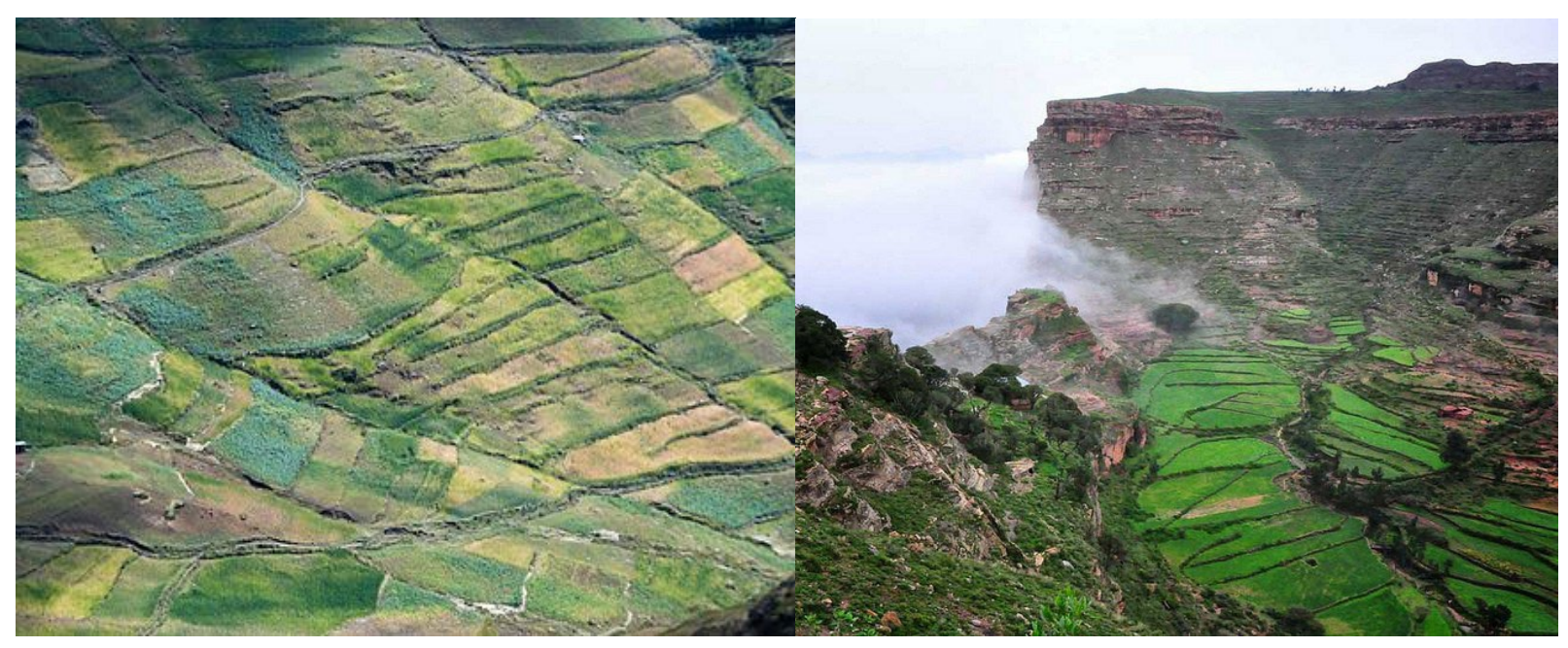

Figure 3: Hilly side land use by extensive terracing

Soil erosion is a major environmental concern affecting $82 \%$ of the country, mainly in the highlands of Ethiopia. It is estimated that Ethiopia loses 400 tons/ha of topsoil every year. The extensive agricultural production systems, the use of environmentally unfriendly technology and overgrazing have contributed to soil erosion in Ethiopia. Over the centuries, deforestation, overgrazing, and cultivation of slopes land has worsened considerably during the 1970s and 1980s eroded the soil. In the dry lowlands, persistent winds also contribute to soil erosion. Soil erosion and land degradation remain one of the most critical and far-ranging environmental issues affecting the country since the 1970's [24]. 


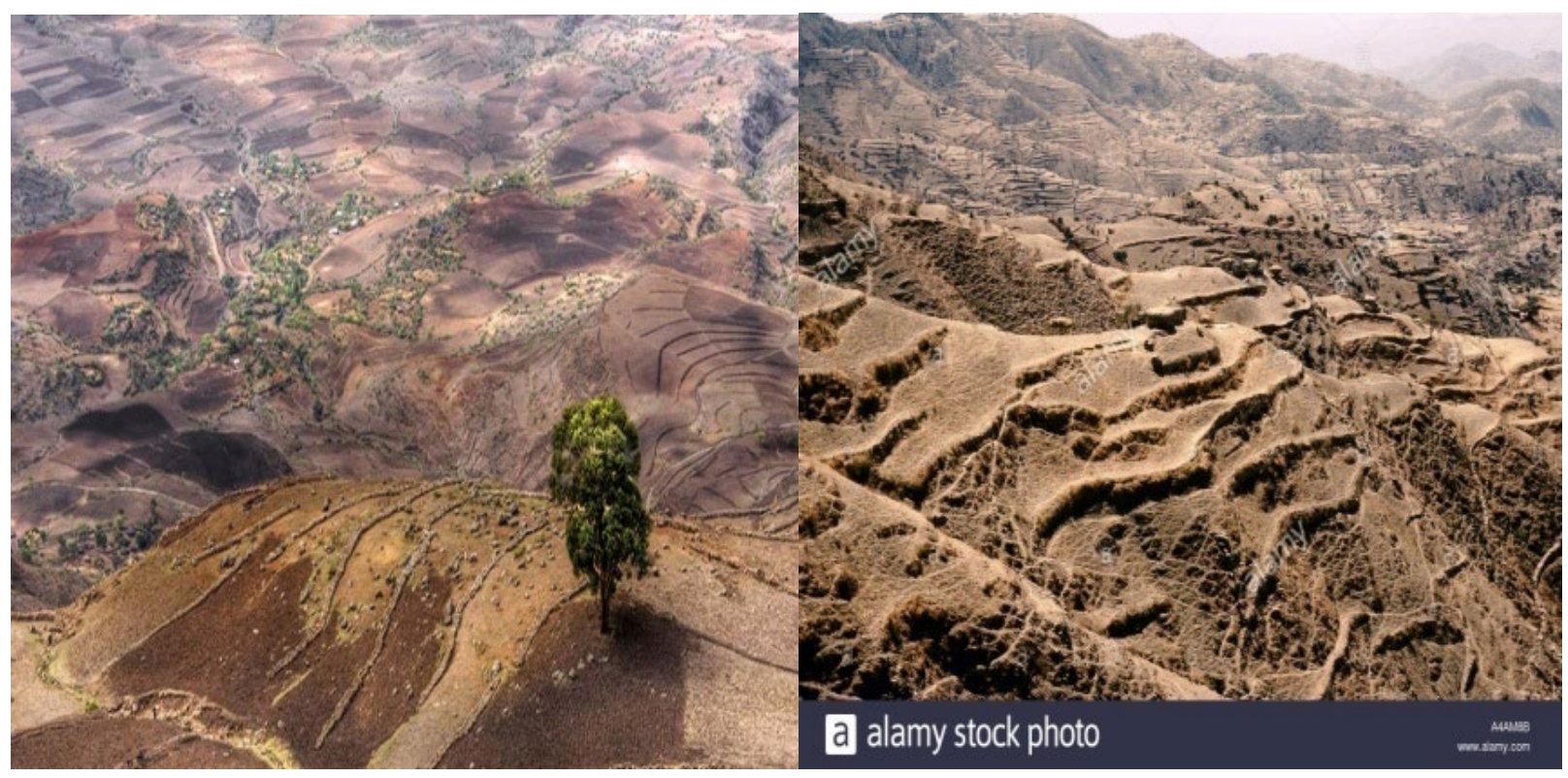

Figure 4: Soil erosion by unpredictable rain

Deforestation is also a major issue in Ethiopia since it is one of the main causes of the prevailing land degradation. Deforestation has accelerated in recent years, especially in the last three decades, in response to a rapidly growing human population and expansion of agricultural activity [25]. Similarly, concerning the issues of deforestation, and environmental degradation the articles of Bahru Zewude, and Richard Pankhurst are the best reference. These scholars present historical evidence of deforestation and land-use change in the $19^{\text {th }}$ and $20^{\text {th }}$ centuries in Ethiopia because of human activities. They argued that deforestation in the country has caused by several reasons. These are the ever-increasing demand for firewood, cooking, building houses, and converting the forest area into agricultural fields. In the forested areas of the South and South West, deforestation is occurring at a sustained rate with major forestry threats including resettlement, commercial farming and fire. In the eastern and southern lowlands, commercial, agricultural investments, and rangeland enclosures have a detrimental effect on the natural resource availability and the livelihoods of the rural community [26].

As discussed above, forest destruction in Ethiopia caused by population increase, unmanaged human activities, lack of a sense of ownership, government resettlement schemes, fire, and commercial farming. Timber, lumber and other forest product demands of the urban centers are also a major cause of deforestation in Ethiopia. In most rural areas the farmers require land to be cultivated and they deforest the area to plow the land for agriculture. This brings the destruction of flora and fauna of the surrounding region. This has exposed the soil to wind and running water erosions; thus depleting the soil nutrients [27]. Ethiopian farmers have been using fire as a means of farming tool for a long time. Every year, when farmers start preparing their land for agriculture, it is common to see deliberately set fires. Farmers consider it as the cheapest and most common tool used for a variety of production activities. However, there have been times when fires have broken out on a large scale and brought about serious economic, political, social and environmental destruction in Ethiopia. Historically, we remember that high forests of Ethiopia remain victims of war, conflict and forest fires [28]. 


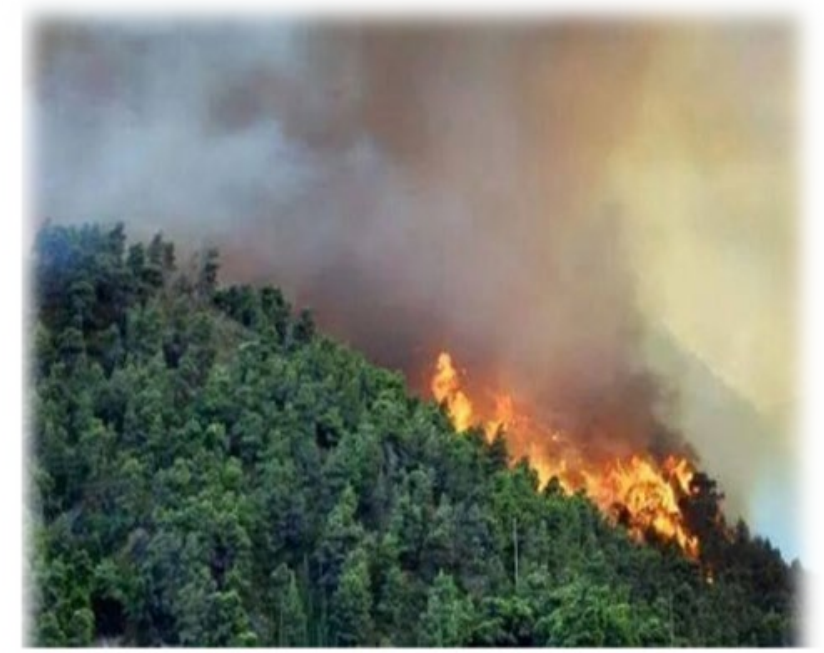

Galema forest in Chilalo, Oromia State, on fire. 2nd March 2015

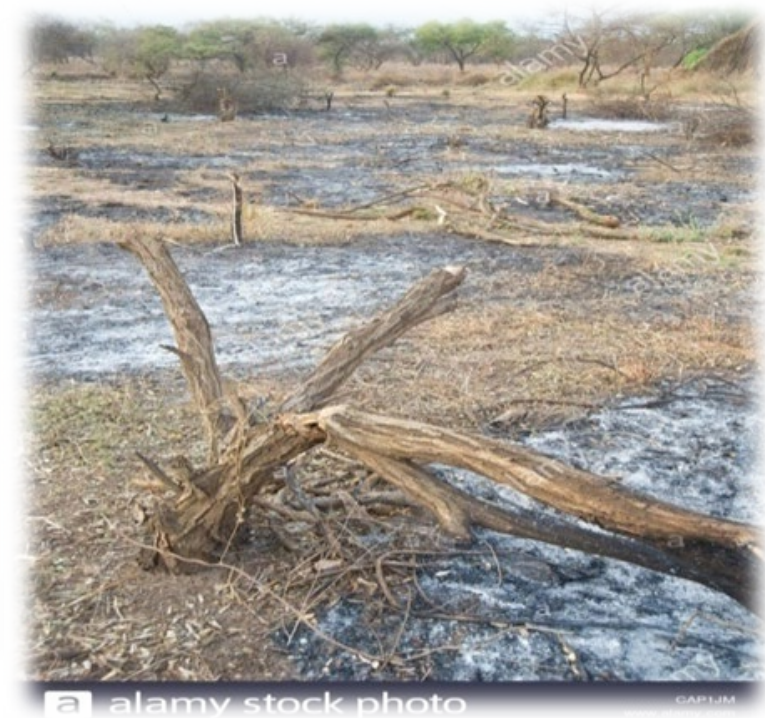

Figure 5: Forest fire caused by human action

As several studies confirmed it in 1984 fires damaged approximately 308,200 ha of natural forests in Ethiopia. In 2000 wildfire has broken out and damaged several resources in Ethiopia. Among the places where forest fires broke out in 2000 were Bale, Borana, Jimma, Ilubabor, East Wellega, East and West Hararghe and Arsi Zones in Oromia Region. It is estimated that over 100,000 ha was affected in Bale and Borana zones alone. Government and local officials agree that the traditional use of fires for agricultural production and the prolonged drought compounded by wind contributed to this forest fire in the year 2000. Nevertheless, many scholars and politicians argue that sometimes forest fires in high forest areas were used for political struggles and to dismiss anti-government bodies [29]. Gebru, on his part, analyses the crushing oppression of the nobility and peasant protests in Ethiopia. He focuses only on the armed struggles of the peasants against the state. However, he does not tell us other dimensions in which the peasants demonstrate their opposition deliberately by devastating forest and used forest fire as a means of political agenda [30].

Furthermore, Ethiopia experienced similar episodes during Ahmad Gragn (1527-1542 A.C.). It is told that Ahmad Gragn ordered his troops to clear and burn all the forests stretching from the eastern lowlands to the central highlands to destroy the strategic position of Emperor Libne Dingil soldiers [31]. Negatively, forest fires caused the release of carbon dioxide and the consumption of atmospheric oxygen, the disruption of energy flow and the pollution of the atmosphere and water bodies. Besides, a forest fire may radically change the environment and affect soils physically, biologically and chemically. The environmental degradation of the forest fires has resulted in the loss of many valuable indigenous trees and endemic wild animals. [32].

\section{CLIMATE CHANGE AND THE IMPACT ENVIRONMENTAL POLLUTION}

Ethiopia's urban environments are characterized by unplanned urbanization, a very high population, high density of housing and unplanned settlement, crowded market centers, and poor infrastructure. They are created by accident and the social services cannot support the ever-increasing migration. In these overcrowded 
urban settlements of Ethiopia, waste disposal facilities such as toilets, garbage and sewerage are exposed to the environment and it causes health problems such as diarrhea, intestinal infections and influenza. Although the industrial sector is said to be at its infant stage in Ethiopia and there are releasing untreated discharge into the surrounding rivers and other water bodies. Besides, lack of environmental awareness concerning the linkage between environment and development, weak participation of the people and environmental management activities are some of the major environmental challenges in Ethiopia [33].

There are great impacts of climate change on human health, the environment, agriculture, water supply, sanitation and socioeconomic activities in Ethiopia. It poses huge challenges to rain-fed agricultural economic development countries. Historically, climatic change in Ethiopia brought recurrent droughts, famine and heavy rainfall in different parts of the country. Increased heavy rainfall and it cause soil erosion, crop damage and water logging, which makes the land difficult to cultivate for agriculture. It is estimated that Ethiopia loses more than 1.5 billion tons of fertile soil each year through heavy rain and flooding [34].

Moreover, in relation to this, the main causes of livestock deaths in Ethiopia are shortages of water and food during drought. Changes in rainfall and warmer temperatures caused the survival of vectors like flies and mosquitoes that transmit infectious diseases to livestock. For several decades there have been losses of livestock-associated with drought in Borana zone, southern Ethiopia. In addition to affecting agriculture and livestock, floods can also cause huge damage to property, livelihoods and infrastructure. On the other hand, climate change is expected to increase the surface temperature of the Earth and the oceans, raise sea levels, alter the global distribution of rainfall, affect the direction of ocean currents and increase the frequency of extreme weather events [35].

Environmental Pollution was defined as the introduction of a waste substance into the environment and the responsibility to cause harm to humans and other living organisms. As several studies that indicate how human activities are polluting our environment, adversely affecting the water, the air, and the soil. These pollutants may be in the form of gas, liquid, solid. Liquid pollutants usually come from liquid waste substances includes human waste, industrial waste and other forms of wastes. Factories generate liquid waste from washing in the manufacturing process, cleaning objects and chemical mixing. Rainwater washes these wastes from the land surface into lakes and rivers. Water pollution is also characterized by the presence of excess physical, chemical, or biological substances that change the qualities of the water, causing harm to living organisms and responsible for many different waterborne diseases. Naturally, water is colorless, odorless and transparent. But, water that tastes or smells bad can be said to have the symptoms of water pollution [36].

Solid waste is any solid material that is assumed not to be useful and thrown away. Factories, businesses and households produce different kinds of solid waste such as paper, plastics, metals, solid chemicals, and pieces of cloths. Domestic sources of pollution include toilets, latrines and waste water from kitchens and bathrooms. If these wastes are properly managed and prevented from getting into the environment, they will not cause pollution [37]. 


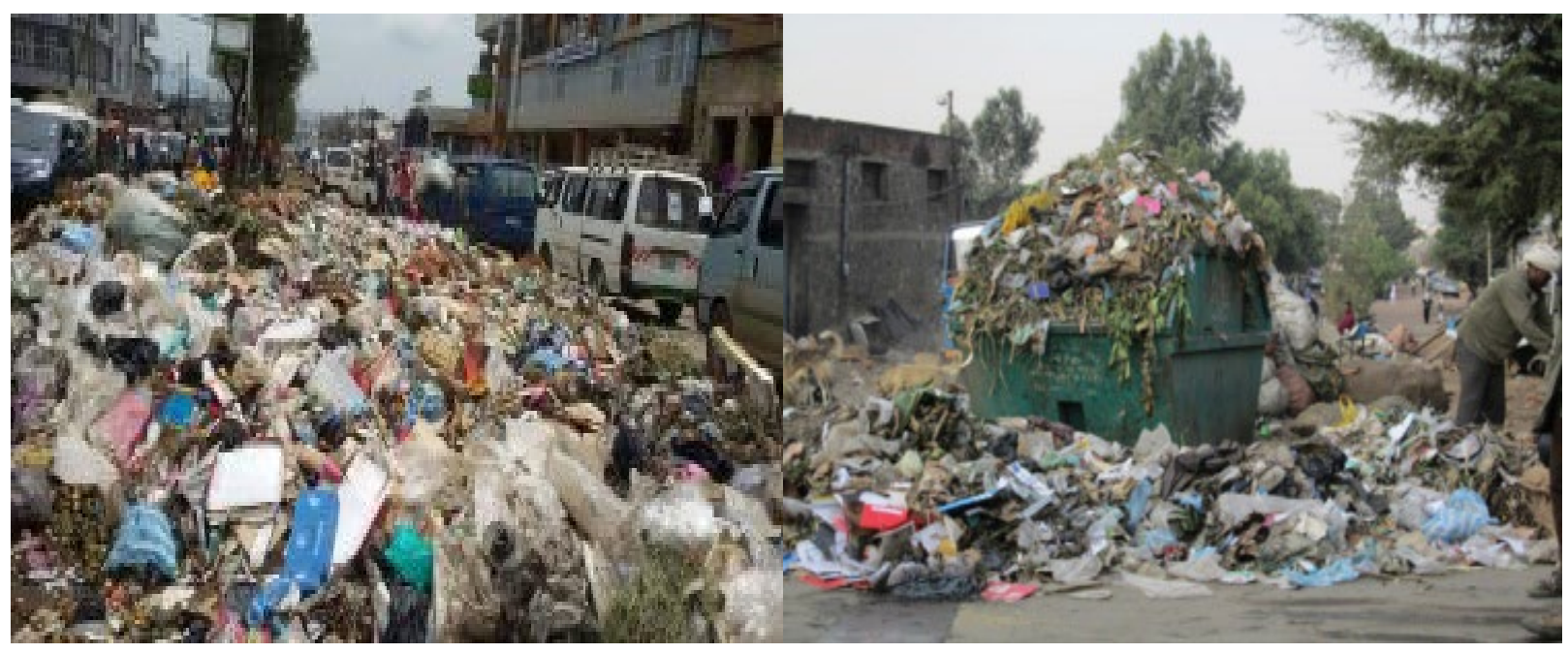

Figure 6: Some domestic source of pollutant waste materials

Many industrial processes produce polluting waste substances that are discharged to the environment. The most polluting industries in Ethiopia are food processing, tanneries and textiles with the processing plants and factories that produce liquid effluents [38].

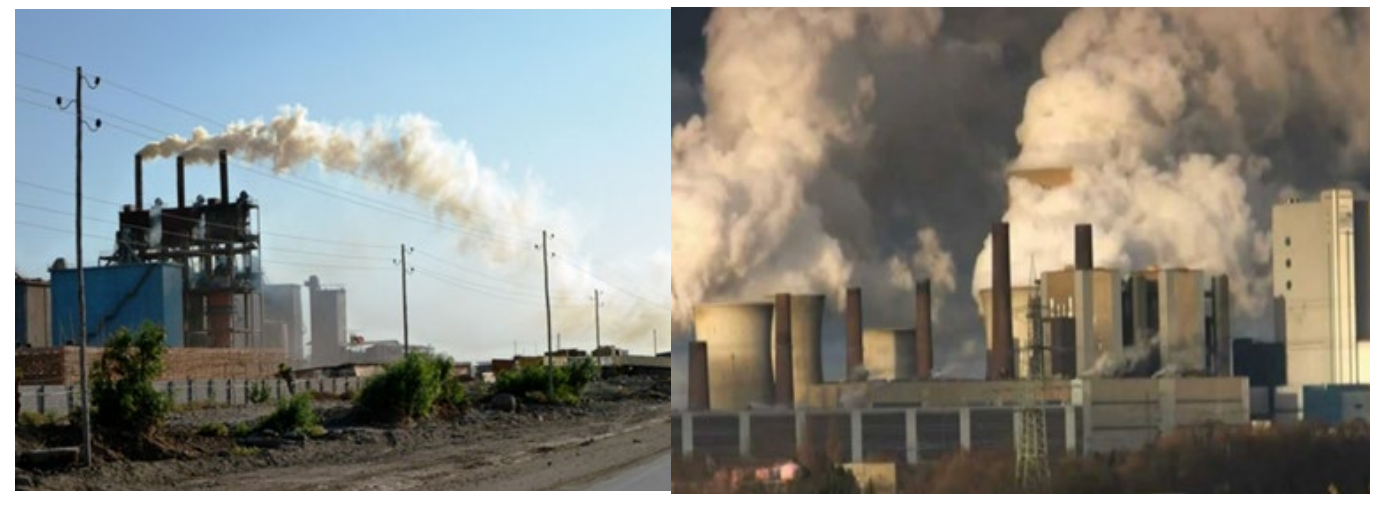

Figure 7: Air pollution from Industrial sector

Moreover, in Ethiopia, Wonji, Metheara and Akakai, Mojo, Gelan, Dukem are industrial towns of the country. The river water is heavily polluted by wastes generated from these industries and noise pollution. In practice, rivers frequently receive polluting discharges from many different tributary sources. [39]. 


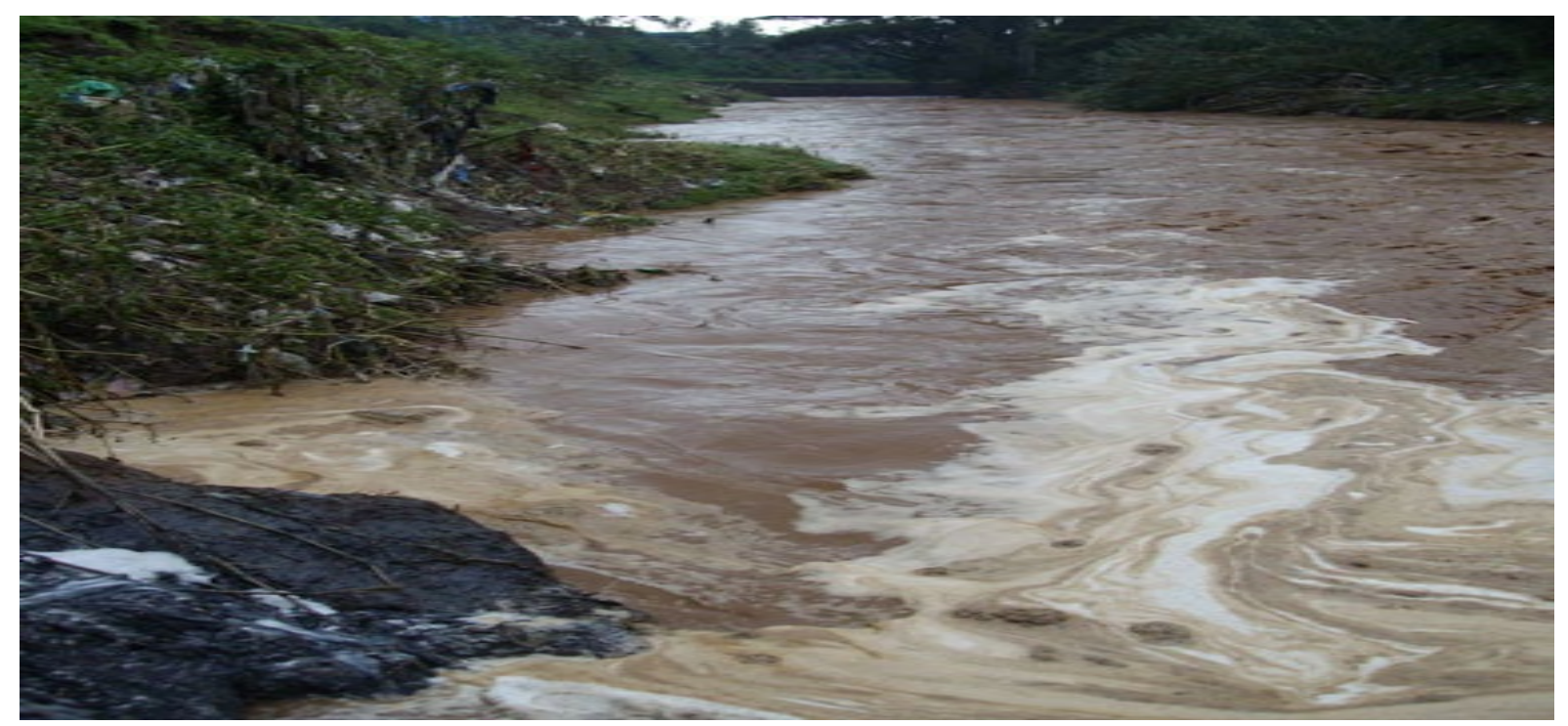

Figure 8: Akaki River Polluted by Industrial waste

Similarly, Industrial Pollution from flower farm production is also another environmental problem in Ethiopia. Flower farming for commercial purposes needs various types of chemicals and pesticides. These chemicals are hazardous to humans and pollute the environment.

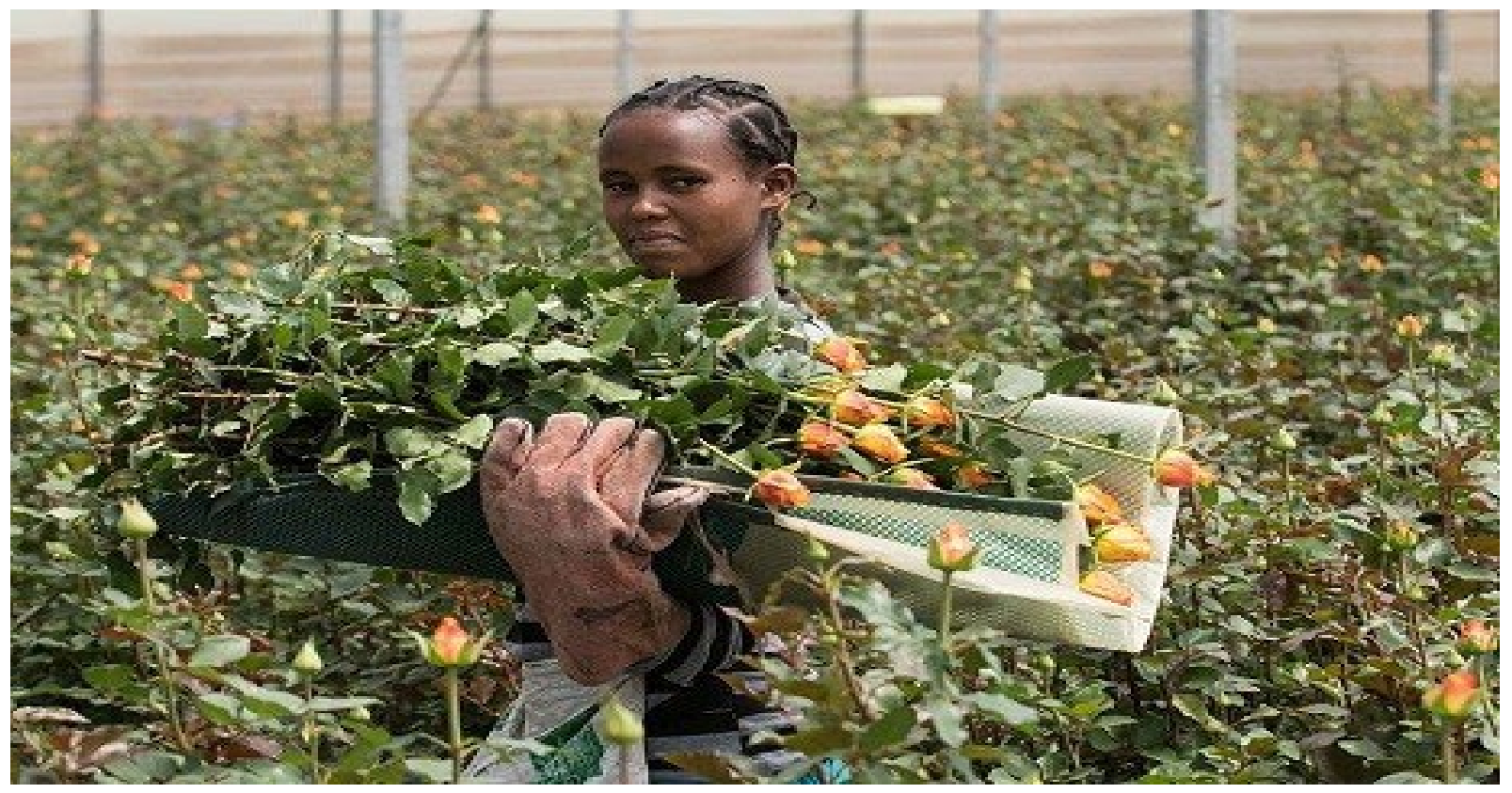

Figure 9: Ethiopia Flower Farming Field

There are varieties of vehicles in town and cities in the country. These vehicles differ not only in their size, but also by using different types of fuel they used such as petrol, diesel, and blended fuel. There are black exhaust 
gases produced by these vehicles. The intensity of the black color is great for poorly maintained vehicles, which makes the air smoky and causes coughing and eye irritation. There is also a lack of strong policy to remove older vehicles from the roads in Ethiopia [40].

Therefore, air Emissions from vehicles and unregulated industry have caused a sharp decline in the air quality of town and cities of Ethiopia. Indoor air pollution is also a very serious issue, especially severe for women and children due to household use of polluting traditional stoves and woody biomass, which accounts for $95 \%$ of the energy supply. Efforts at expanding the infrastructure and industrial base of the country have had negative consequences on the environment. The expansion of irrigation schemes has led to the spread of vector-borne diseases and the displacement of communities. The recent growth of urban areas and industrial establishments has caused the deterioration of the environment through the emission of wastes. The extensive road construction activities in rural Ethiopia have also contributed to soil erosion and loss of forest cover [41]. Agricultural activities in Ethiopia use more pesticides and fertilizers. These chemicals reach water bodies they can cause other problems to the natural environment. Agriculture is also responsible for gaseous pollutants in the form of methane produced by livestock and solid pollutants from crop residues, packaging materials and other wastes similar to those produced domestically [42].

\section{NATURAL RESOURCE MANAGEMENT AND ENVIRONMENTAL PROTECTION IN ETHIO- PIA}

Ethiopia's natural resources (land, water, forests and trees) are fundamental to the survival and livelihood of the majority of people in rural Ethiopia. It is the base for any economic development, food security and other necessities of its people. On the contrary to this, Ethiopia is a country where natural resource degradation has been going on for centuries. Small scale farmers, who depend on these resources, face severe constraints related to intensive cultivation, overgrazing, deforestation, soil erosion, the decline of soil fertility, and water scarcity. These factors paved the way for the decline of crops and livestock products, food insecurity, high population growth rate and environmental degradation [43].

At present it is facing a serious ecological imbalance activated mainly by the fast increment of its population size. This has led to a destructive cycle of land use pattern, involving deforestation followed by continuous cropping and grazing on the soil. Furthermore, Ethiopia's rich natural and cultural heritage is threatened by neglect, decay, removal, and destruction, as well as the less visible and tangible impacts of changing socio-cultural values, foreign ideas, and imported technologies. Dessalegn works for the environment, peasant agriculture and agricultural crisis; he critically analyzes how state policies on the environment impacted the natural environment. Besides, he examines the merit of natural environment conservation, and environmentalism particularly in Central and Northern highland Ethiopia. Nevertheless, there was no government policy on natural resources management in Ethiopia before 1974. After 1975 the Derg government used peasant associations to accelerate conservation work throughout rural areas. The government mobilized farmers and organized "food for work" projects to build terraces and plant trees [44].

Between 1976 and 1985, the government constructed 600,000 kilometers of agricultural embankments on cultivated land and 470,000 kilometers of hillside terraces, and it closed 80,000 hectares of steep slopes for regeneration. Additionally, during 1983-84 the Ministry of Agriculture used "food for work" projects to raise 65 million tree seedlings, plant 18,000 hectares of land, and terrace 9,500 hectares of land. However, the removal of arable land for conservation projects has threatened the welfare of increasing numbers of rural poor. For this reason, some environmental experts maintain that large-scale conservation work in Ethiopia has been ineffective [45]. 

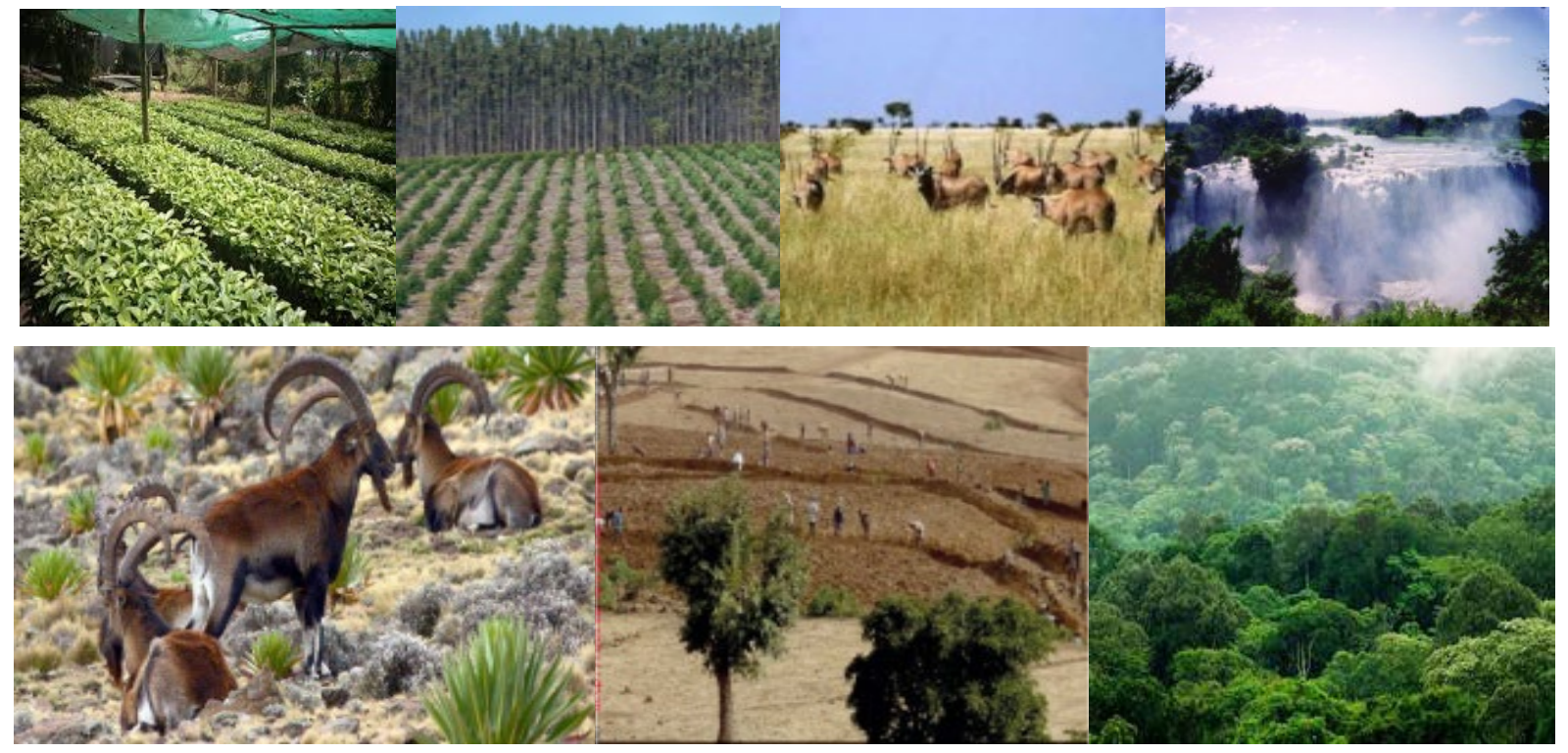

Figure 10: Some areas of Natural Resource Management in Ethiopia since 1990's

The pressure of intense human activity and improper farming and management practices pose serious threats to the sustainability of natural resources and maintaining ecological balance. Therefore, the natural resource management approach makes a systematic effort to enhance sectoral linkages for improved soil, water, forest, and crop and livestock management at the community level. Scholars convey their view as Ethiopia is one of the countries in the world that requires tremendous attention to sustainable land management and environmental protection. As a result of the economic, social and environmental costs of deforestation and natural resource degradation, the Government of Ethiopia took bold actions over the last two decades to reverse the trend. Through continuous environmental sensitization, awareness creation, mass mobilization and engagement, the government has enhanced the solidarity of the rural society and their continuous commitment to environmental campaigns and rehabilitation works [46].

The government also took credible efforts to tackle land degradation and restore degraded areas through sustainable land management options. From the early 1990s, the government took different measures in natural resource management and environmental protection programs. Recently, the country has also adopted a Climate Resilient Green Economy strategy aiming to improve livelihoods and sustain the integrity of the environment. Hence, millions of hectares of land have been reserved for natural regeneration, billions of trees have been planted, a million kilometers of terraces have been constructed, hundreds of thousands of hectares of land have been protected from unlimited livestock and human intervention and thousands of water harvesting and development schemes have been developed in various parts of the country [47].

\section{CONCLUSION AND RECOMMENDATION}

Before 1945 Ethiopia was considered as "Dark Age" in the environmental movement. It was the period when environmental issues are declined, the period when environmental degradations accelerated and the government policies excluded the environmental matters in Ethiopia. In the second half of the $20^{\text {th }}$ century, the country has experienced a severe environmental crisis such as climatic change, deforestations, drought, famine, soil erosion and land degradation. The major pushing factors are population pressure, agricultural expansion, and air pollution complimented with the ignorance of the indigenous knowledge, top-down approach of the 
government policies. These issues were causing significant consequences for the population dependent upon the environment as their primary source of income. However, during the 1960s greater emphasis given to environmentalism and environmental issues take a great role in the county policy. Some scholars consider this era as an 'environmental movement' in the country. Environmental policies during the Derg era were based on the socialist ideologies.

In 1975 land reform brought some significant contribution to the forestry sectors. The government as well as donor agencies started to provide financial and technical assistance to environmental conservation in general and the forestry sector in particular. Nevertheless, the environmental policies of the Derg regime were also characterized by top-down management policies, incorporated extensive conservation and tree-planting initiatives without careful planning, and lack of the merit of indigenous environmental conservation practices. The transition from the Derg regime to the current EPRDF was accompanied by a radical ideological shift in the development of formal environmental institutions. Ethiopia has great agricultural potential because of its vast areas of fertile land, diverse climate, adequate rainfall and large labor pool. Despite this potential, however, Ethiopian agriculture has remained underdeveloped. Therefore, lack of environmental awareness, weak participation of the people and environmental management activities are some of the environmental challenges in Ethiopia. Nowadays, the government took credible efforts to tackle environmental degradation and restore degraded areas through sustainable land management options. The government also took different measures in natural resource management and environmental protection programs aiming to improve sustainable livelihoods and development. Hence, several hectares of land were reserved for natural regeneration, trees planting, terracing, land protection from unlimited livestock and human intervention and water harvesting has been developed in various parts of the country.

Based on the foregoing discussions, the following recommendations could be forwarded to ensure environmental concern in Ethiopia. There is a tremendous need for more environmental education to increase public environmental awareness at various levels of society. The integration of scientific and indigenous knowledge is also helpful in research on the environment. Research helps in assessing and publicizes the gravity of environmental problems, developing adaptation methods for different problems. It is also essential to integrate environmental considerations into all national development plans, sectoral policies, and programs. Stronger institutions, experts, and partnerships among stakeholders are needed to solve environmental problems from the grassroots. Governmental and nongovernmental actors and the donor community must collaborate and coordinate their activities to achieve better results, and encourage the participation of different stakeholders in decision-making at all levels. In Ethiopian, there is rule-oriented approach, low enforcement capacity, and also legal gaps in the implementation of policy documents. Legislative action must establish standards for different environmental concerns. Furthermore, establish strong planning, monitoring and evaluation systems on the environmental policy of the country. In general, for the future well-being of our environment depending on good politics, integrated efforts of all concerned bodies working with the environment and adequate support of our overseas partners and international communities are very essential.

\section{REFERENCE}

1. Shibru and Kifle Lemma,( 1998): environmental management in Ethiopia has the national conservation plans worked? Environmental Forum Publications Series No.1 organization for social science research in eastern and southern Africa (OSSREA) Addis Ababa,

2. Tadese Kidane-Mariam (2001)“Changes and Continuities in Africa's Post independent

Environment and Habitat Management Paradigms and Policies: The Case of Ethiopia

and Ghana." Iowa University, PhD Dissertation in Geography.

3. Ibid

American Research Journal of History and Culture 
4. Donald, Crummey (1986) "Deforestation in Wallo: Process or Illussion?" in Journal of Ethiopian Studies. Vol.13,No.1

5. Dessalegn Rahmato( 2001) Environmental change and state policy in Ethiopia: lessons from past experience forum for social studies Addis Ababa.

6. Bekele, Melaku ( 2008)“Ethiopia's Environmental Policies, Strategies and Programs”. Digest of Ethiopia's National Policies, Strategies \& Programs. Addis Ababa: Forum for Social Studies .

7. Dessalegn Rahmato( 2001) Environmental change and state policy in Ethiopia: lessons from past experience forum for social studies Addis Ababa.

8. Chala Dechassa (2015) Environmental Management System: During Imperial, Derge and EPRDF Periods in Ethiopia: Review Paper; Journal of Environment and Earth Science Vol.5, No.3

9. Bekele, Melaku (2008)“Ethiopia’s Environmental Policies, Strategies and Programs”. Digest of Ethiopia's National Policies, Strategies \& Programs. Addis Ababa: Forum for Social Studies.

10. Ibid

11. Melaku Bekele(1998) The Ethiopian Forest from Ancient Time to 1900: A Brief Account (The Case of Northern Ethiopia). Walia 18: 3-9.

12. Dessalegn Rahmato( 2001) Environmental change and state policy in Ethiopia: lessons from past experience forum for social studies Addis Ababa.

13. Bekele, Melaku (2008)“Ethiopia's Environmental Policies, Strategies and Programs”. Digest of Ethiopia's National Policies, Strategies \& Programs. Addis Ababa: Forum for Social Studies .

14. Chala Dechassa (2015) Environmental Management System: During Imperial, Derge and EPRDF Periods in Ethiopia: Review Paper; Journal of Environment and Earth Science Vol.5, No.3

15. Gedion Getahun (2000) The Environmental Strategy of Ethiopia at Present and Beyond.

16. Ibid

17. Shibru and Kifle Lemma,(1998): environmental management in Ethiopia has the national conservation plans worked? Environmental Forum Publications Series No.1 organization for social science research in eastern and southern Africa (OSSREA) Addis Ababa,

18. James McCann, People of the Plow: an agricultural history of Ethiopia, 1800-1990 (Madison, 1995), 84-108.

19. Ibid 
20. Donald, Crummey (1986) “Deforestation in Wallo: Processor Illussion?" in Journal of Ethiopian Studies. Vol.13,No.1

21.Sahlu Haile, (2004): Population, Development, and Environment in Ethiopia, Environmental Change and Security Project. Special Report, Issue 10.

22. Mesfin Wolde Mariam (1984) Rural Vulnerability to Famine in Ethiopia, 1958-1977 (New Delhi, 35-36.

23. Richard Pankhurst (1966), "The Great Ethiopian Famine of 1889-92: a New Assessment", Journal of the History of Medicine and Allied Sciences , 95-124,271-94.

24. Shibru and Kifle Lemma (1998): environmental management in Ethiopia has the national conservation plans worked? Environmental Forum Publications Series No.1 organization for social science research in eastern and southern Africa (OSSREA) Addis Ababa,

25.Bahru Zewde (1976), "A Historical Outline of Famine in Ethiopia, "in Abdul Mejid Hussein (ed.), Rehab: Drought and Famine in Ethiopia (London,), 52-58.

26. Chala Dechassa (2015) Environmental Management System: During Imperial, Derge and EPRDF Periods in Ethiopia: Review Paper; Journal of Environment and Earth Science

Vol.5, No.3

27. Ibid

28. Dechassa Lemessa(2001) Forest fires in Ethiopia: Reflections on socio-economic and environmental effects of the fires in 2000; UN-Emergencies Unit for Ethiopia \& Matthew Perault, Brown University, Providence, USA.

29. Dessalegn Rahmato( 2001) Environmental change and state policy in Ethiopia: lessons from past experience forum for social studies Addis Ababa.

30.Gebru (1996)

31. Bekele, Melaku. 2008.“Ethiopia's Environmental Policies, Strategies and Programs”. Digest of Ethiopia's National Policies, Strategies \& Programs. Addis Ababa: Forum for Social Studies .

32. Dechassa Lemessa (2001) Forest fires in Ethiopia: Reflections on socio-economic and environmental effects of the fires in 2000; UN-Emergencies Unit for Ethiopia \& Matthew Perault, Brown University, Providence, USA.

33. Sahlu Haile, (2004): Population, Development, and Environment in Ethiopia, Environmental Change and Security Project. Special Report, Issue 10.

34 . Helena Kahiluoto \& Reimund Rotter (2009) Implications of and possible responses to climate change University of Helsinki Department of Economics and Management.

35. Rahman, A (2008) Climate change and the future of smallholder agriculture. How can rural poor people be a part of the solution to climate change? IFAD Policy Reference Group on Climate Change. 
36. Sahlu Haile, (2004): Population, Development, and Environment in Ethiopia,Environmental

Change and Security Project. Special Report, Issue 10

37. Ibid

38. Rahman, A (2008) Climate change and the future of smallholder agriculture. How can rural poor people be a part of the solution to climate change? IFAD Policy Reference Group on Climate Change.

39. Chala Dechassa (2015) Environmental Management System: During Imperial, Derge and EPRDF Periods in Ethiopia: Review Paper; Journal of Environment and Earth Science

Vol.5, No.3

40 . Rahman, A (2008) Climate change and the future of smallholder agriculture. How can rural poor people be a part of the solution to climate change? IFAD Policy Reference Group on Climate Change.

41. Shibru and Kifle Lemma( 1998): environmental management in Ethiopia has the national conservation plans worked? Environmental Forum Publications Series No.1 organization for social science research in eastern and southern Africa (OSSREA) Addis Ababa,

42. Badege Bishaw (2001)“Deforestation and Land Degradation in the Ethiopian Highlands: A Strategy for Physical Recovery," in Northeast African Studies.Vol. 8, No. 1.

43. Ibid

44. Dessalegn Rahmato(2001) Environmental change and state policy in Ethiopia: lessons from past experience forum for social studies Addis Ababa.

45.KelbessaWorkineh(2010)IndigenousandModernEnvironmentalEthics:AStudyoftheIndigenous Oromo Environmental Ethic and Modern Issues of Environment and Development.

Ethiopian Studies I. Washington, DC: Council for Research in Values and Philosophy. 46. Alemneh Dejene ( 2003) Integrated Natural Resources Management to Enhance Food

Security: The Case for Community-Based Approaches in Ethiopia Environment and Natural Resources Service, Research, Extension and Training Division FAO Sustainable Development Department.

47. Ibid

Citation: Endalkachew Lelisa Duressa , "Environmental Dynamics and Its Impact on Agricultural Sustainability in Some Vulnerable Areas of Ethiopia Since 1900's: An overview". American Research Journal of History and Culture, vol 6, no. 1, 2020, pp. 1-18.

Copyright (c) 2020 Endalkachew Lelisa Duressa, This is an open access article distributed under the Creative Commons Attribution License, which permits unrestricted use, distribution, and reproduction in any medium, provided the original work is properly cited. 